\title{
Development, growth, and survivorship of the copepod Calanus marshallae in the laboratory
}

\author{
William T. Peterson \\ Marine Sciences Research Center, SUNY-Stony Brook, Stony Brook, New York 11794, USA
}

\begin{abstract}
Development times from egg to adult Calanus marshallae (Copepoda, Crustacea) were $36 \mathrm{~d}$ at $15^{\circ} \mathrm{C}, 62 \mathrm{~d}$ at $11^{\circ} \mathrm{C}$ and $64 \mathrm{~d}$ at $10^{\circ} \mathrm{C}$. Stage-by-stage development was not isochronal but followed a sigmoidal pattern. Egg, N1 and N2 together took $3.4 \mathrm{~d}$ at $10^{\circ} \mathrm{C}(=5.3 \%$ of the total development time). $\mathrm{N} 3$ had the second longest duration of any stage $\left(6.8 \mathrm{~d}\right.$ at $10^{\circ} \mathrm{C} ; 10.7 \%$ of total development). Stage duration decreased from N3 through N6, with N6 having the shortest duration of any stage $(2.6 \mathrm{~d})$, then development became progressively slower through each copepodite stage. C5 had the longest duration $(20.9 \mathrm{~d} ; 32.8 \%$ of total development time). Body lengths of laboratory-raised stages $\mathrm{N} 1$ to $\mathrm{C} 3$ were the same as of field-collected specimens; $\mathrm{C} 4$ and $\mathrm{C} 5$ were shorter than in wild copepods, but laboratory-raised females were significantly longer than wild females. This suggests that laboratory growth conditions were probably as good as, if not better than, conditions in the field. Weight was gained at a rate of $0.05 \mu \mathrm{g} \mathrm{\mu g}^{-1} \mathrm{~d}^{-1}$ from egg through $\mathrm{N} 4 ; 0.18 \mathrm{~d}^{-1}$ from $\mathrm{N} 5$ to $\mathrm{C} 5 ; 0.02 \mathrm{~d}^{-1}$ from $\mathrm{C} 5$ to adult female. It is argued that observed deviations from isochronal development in Calanus marshallae may reflect differential mortality rates among developmental stages such that stages that on average experience high mortalities will develop most rapidly
\end{abstract}

\section{INTRODUCTION}

The copepod Calanus marshallae is common in the zooplankton of the coastal upwelling zone of the northeast Pacific Ocean off Washington, Oregon and northern Caifornia, USA (Peterson \& Miller 1975, 1977). Individual $C$. marshallae were often referred to as Calanus finmarchicus until Frost (1974) showed that it was a third sibling species within a Calanus finmarchicus' complex: C. marshallae in the North Pacific, along with $C$. finmarchicus in the north Atlantic, and C. glacialis in the Arctic Ocean. Even though all 3 species are morphologically similar, their life-history characteristics may be quite different because each is adapted to a different environment. Aspects of the life history and ecology of C. finmarchicus and C. marshallae have been worked out by Marshall \& Orr (1955) and Peterson (1980), respectively.

This paper presents information on several life history parameters for Calanus marshallae including development, growth and survivorship, where possible in comparison with similar data for C. finmarchicus, for other Calanus species, and other coastal copepods (e.g. Landry 1983). Both laboratory and field data are pre- sented. All results are discussed within a framework of life history and evolutionary ecology.

\section{METHODS}

Female Calanus marshallae were collected 5 to $10 \mathrm{~km}$ offshore from Newport, Oregon, USA. To start an experiment on development time, a known number of eggs was placed in a glass Petridish. After hatching, the nauplii were pipetted to glass containers $(600 \mathrm{ml}$ to 3.8 l) where all subsequent development took place. All laboratory work was done under continuous low light intensity except for 1 experiment (Exp 'I'; Table 2) under a $12 \mathrm{~h}$ LD cycle. Copepods were fed excess amounts of a mixture of the diatom Thalassiosira weissflogii and the flagellate Isochrysis galbana, grown in batch cultures at $12^{\circ} \mathrm{C}$ using $\mathrm{f} / 2$ medium (Guillard \& Ryther 1962). New phytoplankton cultures were inoculated at weekly intervals ensuring that food provided to the copepods was always in log phase and never more than $1 \mathrm{wk}$ old. Twelve $10^{\circ} \mathrm{C}$ experiments were started with eggs of females collected in January and February 1977, five $11^{\circ} \mathrm{C}$ experiments in June and 
July 1976, and two $15^{\circ} \mathrm{C}$ experiments in August 1977. Nine of the $10^{\circ} \mathrm{C}$ experiments began from single clutches of eggs of individual females. All other experiments began with eggs from several females.

Preliminary experiments showed that mortality of nauplii and early copepodites was high with dense concentrations of phytoplankton so these were avoided. When nauplii were developing, diatoms were kept at ca 2,000 cells $\mathrm{ml}^{-1}$, and the flagellate at ca 50,000 cells $\mathrm{ml}^{-1}$ (cell counts determined by microscope). When copepodites appeared, Thalassiosira weissflogii was increased to ca 6,000 cells $\mathrm{ml}^{-1}$. Cell counts were converted to carbon units using Strathmann's (1967) equation: Carbon $=0.378 \cdot \mathrm{V} \cdot \exp$ 0.758 . The mean cell volume (V) of the Thalassiosira clone was $2,100 \mu^{3}$, equal to $125 \mathrm{pg} \mathrm{C}$ cell ${ }^{-1}$. Therefore the food concentrations in the experiments ranged from 250 to $750 \mu \mathrm{g} \mathrm{C} \mathrm{l}^{-1}$ over the range of 2,000 to 6,000 cells $\mathrm{ml}^{-1}$ of the diatom. Each experimental container was inspected daily for food build-up or depletion, and phytoplankton was added as needed. Copepods in Experiments ' $H$ ' through ' $N$ ' (Table 2) were fed twice daily, and in Experiments ' $M$ ' and ' $N$ ', copepods were fed such excess amounts of $T$. weissflogii as to color the water yellow-brown. Fecal pellets and other debris were removed from the containers daily, or as necessary. The containers were not stirred because the particular clone of $T$. weissflogii which was used remained in suspension without stirring.

A census was made of the copepods in the 10 and $11^{\circ} \mathrm{C}$ experiments at weekly intervals, and at $4 \mathrm{~d}$ intervals in the $15^{\circ} \mathrm{C}$ experiments. On the census day, water in each container was gently poured through a $64 \mu \mathrm{m}$ Nitex screen and the copepods rinsed into a Petridish. Individuals were enumerated by developmental stage then returned to the experimental containers. Anesthetics were never used.
Stage-specific development times and stage duration were calculated from observed changes in stagefrequency over time. Through regression analysis of the data on percent-frequency of stage over time, the median development time (MDT) was calculated, following Landry (1983) and Vidal (1980). Three regression analyses were performed: ordinary least-squares, ordinary least-squares with arc sine transformation of the percents (Sokal \& Rohlf 1981), and a non-parametric regression technique (the Brown-Mood method; Daniel 1978).

For analysis of growth during these experiments, total length of individuals was measured from the tip of the head to the end of the furcae (not including furcal rami). Weights were obtained from unpreserved copepods. Various life cycle stages were removed from plankton collections or laboratory cultures, placed on absorbent paper, rinsed with 1 drop of distilled water, transferred to a piece of aluminum foil, dried overnight at $60^{\circ} \mathrm{C}$, then weighed using a Cahn Gram Electrobalance.

\section{RESULTS}

\section{Survivorship}

Survival from egg to adult at $10^{\circ} \mathrm{C}$ (Fig. 1) ranged from 10 to $68 \%$ (mean $=41 \%$ ). Mortality was highest during the first $40 \mathrm{~d}$ of development (to fifth copepodite) after which it dropped to zero in most experiments. Survivorship from egg to adult in the five $11^{\circ} \mathrm{C}$ experiments averaged $15 \%$; in the two $15^{\circ} \mathrm{C}$ experiments, 0 and $19 \%$ respectively. At $15^{\circ} \mathrm{C}, 7$ of 9 individuals in 1 experiment died before the molt into fifth copepodite; the remaining 2 died during $\mathrm{C} 5$ stage. The other $15^{\circ} \mathrm{C}$ experiment produced 5 adult females from 26 eggs.

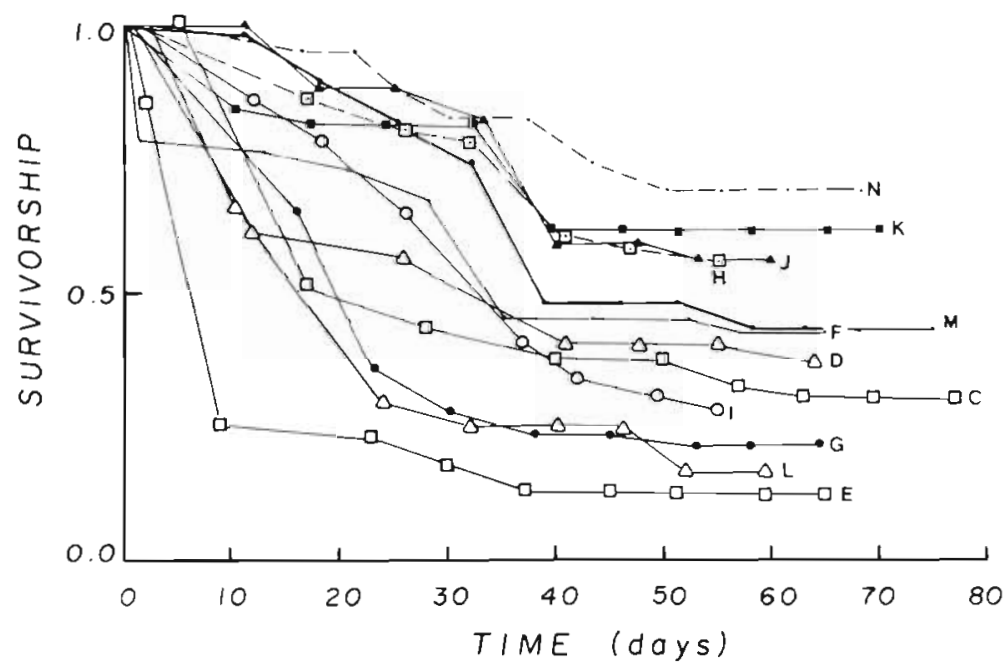

Fig. 1. Calanus marshallae. Survivorship in $10^{\circ} \mathrm{C}$ experiments. Letters: experiments listed in Table 2 
The twelve $10^{\circ} \mathrm{C}$ experiments began with a total of 551 eggs, 136 of which became adult females and 1 a male. Many of these laboratory-born females were maintained for more than 2 mo after adulthood was reached; the single male was kept alive for $73 \mathrm{~d}$ before being preserved. Longevities of field-collected copepods were similar. Wild females were maintained for up to $77 \mathrm{~d}$ and males for $50 \mathrm{~d}$ before being preserved.

\section{Development at $10^{\circ} \mathrm{C}$}

Fig. 2 shows the cumulative percent of the population that was younger than each indicated developmental stage, for the fourth nauplius through female, for all experiments. Estimates of median development times (MDT) calculated from each of the 3 regression methods are listed in Table 1 . The 3 methods gave nearly identical results; hence for all subsequent andlyses the MDT calculated from ordinary least-squares methods will be used. Estimates of developmental rates of eggs and development time to the third nauplius stage come from direct observations. Egg hatching times were as follows: $42 \mathrm{~h}$ at $9.2^{\circ} \mathrm{C}$ and $9.4^{\circ} \mathrm{C}$; $41.3 \mathrm{~h}$ at $9.5^{\circ} \mathrm{C}_{i} 40.0 \mathrm{~h}$ at $10.0^{\circ} \mathrm{C} ; 39 \mathrm{~h}$ at $10.8^{\circ} \mathrm{C}_{i}$ 2 observations of $39 \mathrm{~h}$ at $11^{\circ} \mathrm{C}_{i} 38.8 \mathrm{~h}$ at $11.5^{\circ} \mathrm{C} ; 37 \mathrm{~h}$ at $12.0^{\circ} \mathrm{C}$; less than $24 \mathrm{~h}$ at $15^{\circ} \mathrm{C}$. Most eggs hatched within $30 \mathrm{~min}$ of each other, so the variance in hatching time was not great. The average time from egg laying to the beginning of the third nauplius stage was $85 \mathrm{~h}$ (mean of 4 experiments; $\mathrm{s}_{\overline{\mathrm{x}}}=7.2 \mathrm{~h}$ ). The combined duration of nauplius Stages 1 and 2 (time from hatching to the beginning of nauplius Stage 3) was $45 \mathrm{~h}$, an average of $22.5 \mathrm{~h}$ stage $^{-1}$

Median development time (MDT), duration of each developmental stage, and percentage of the total
Fig. 2. Calanus marshallae. Scattergrams of cumulative percent of the population that was as young, or younger, than the indicated stage, vs time, in the $10^{\circ} \mathrm{C}$ experiments. The 2 lines shown on each panel are regressions calculated from parametric (-) and nonparametric (- - -) techniques. Regression equations and correlation coefficients are from parametric analysis

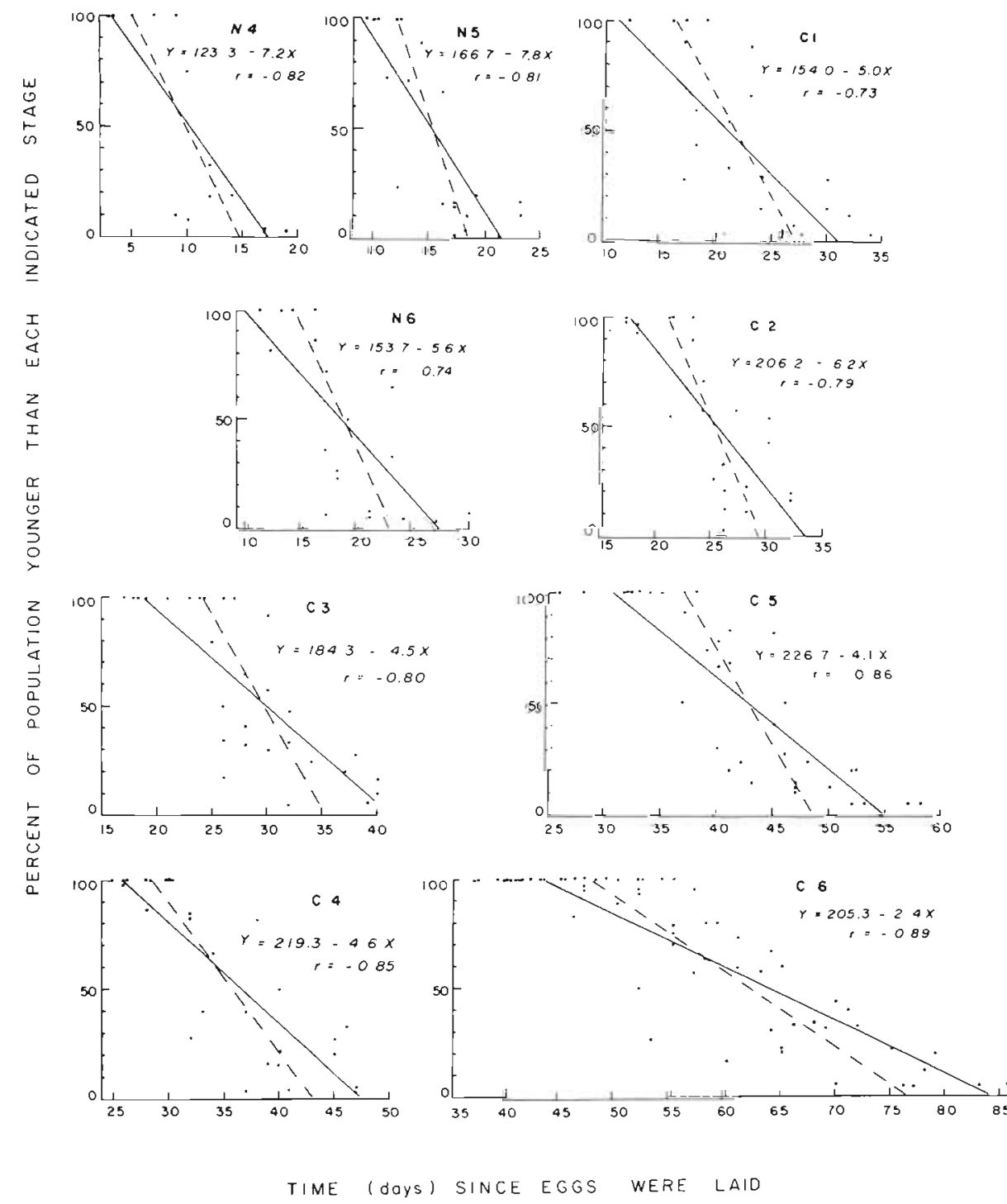


Table 1. Calanus marshallae. Median development time (MDT), in days to reach each successive developmental stage at 3 temperatures. MDT was calculated from 12 experiments at $10^{\circ} \mathrm{C} ; 5$ at $11^{\circ} \mathrm{C}$; 2 at $15^{\circ} \mathrm{C}$

\begin{tabular}{|c|c|c|c|c|c|c|c|}
\hline Stage & $\begin{array}{c}\text { Median dev } \\
\text { Non } \\
\text { parametric }\end{array}$ & $\begin{array}{l}\text { pment tim } \\
\text { Least } \\
\text { ordinary }\end{array}$ & $\begin{array}{l}\text { T), } 10^{\circ} \mathrm{C} \\
\text { ArC } \\
\sin \end{array}$ & $\begin{array}{c}\text { Stage } \\
\text { duration } \\
\text { (d) }\end{array}$ & $\begin{array}{l}\% \text { of } \\
63.8 \mathrm{~d}\end{array}$ & $\begin{array}{l}M D T \\
11^{\circ} \mathrm{C}\end{array}$ & $\begin{array}{l}\mathrm{MDT} \\
15^{\circ} \mathrm{C}\end{array}$ \\
\hline $\mathrm{Egg}$ & - & - & - & 1.6 & 2.5 & - & - \\
\hline N1 & - & - & - & 0.9 & 1.4 & - & - \\
\hline N2 & - & - & - & 0.9 & 1.4 & - & - \\
\hline N3 & - & - & - & 6.8 & 10.7 & 3.4 & - \\
\hline N4 & 10.0 & 10.2 & 10.9 & 4.8 & 7.5 & 10.3 & 5.8 \\
\hline N5 & 15.1 & 15.0 & 15.4 & 3.4 & 5.3 & 13.9 & 8.5 \\
\hline N6 & 18.6 & 18.4 & 18.9 & 2.6 & 4.1 & 17.1 & 8.5 \\
\hline $\mathrm{C} 1$ & 21.6 & 21.0 & 21.6 & 4.3 & 6.7 & 20.4 & 8.6 \\
\hline $\mathrm{C} 2$ & 25.6 & 25.3 & 25.7 & 4.6 & 7.2 & 24.1 & 13.4 \\
\hline C3 & 29.8 & 29.9 & 30.8 & 6.8 & 10.7 & 26.7 & 15.6 \\
\hline $\mathrm{C} 4$ & 35.8 & 36.7 & 37.3 & 6.2 & 9.7 & 35.0 & 19.2 \\
\hline C5 & 41.0 & 42.9 & 43.8 & 20.9 & 32.8 & 41.4 & 27.1 \\
\hline C6 & 62.2 & 63.8 & 64.5 & $>75$ & & 62.3 & 35.8 \\
\hline
\end{tabular}

development time represented by each stage is given in Table 1. Median development times for each stage in the $10^{\circ} \mathrm{C}$ experiments are plotted in Fig. 3A. The overall pattern in development from $\mathrm{N} 3$ to $\mathrm{C} 5$ can be approximated by a linear function with a slope of $4.6 \mathrm{~d}$ stage $^{-1}$. However, the true pattern of development seems to follow a sigmoidal model with periods of rapid development alternating with periods of slower development. Median development times for the 11 and $15^{\circ} \mathrm{C}$ experiments are also listed in Table 1 and plotted in Fig. 3B. The MDTs for each stage at these temperatures were faster than those at $10^{\circ} \mathrm{C}$, and the overall pattern of development is sigmoidal, rather than linear.

\section{Variability in developmental rates}

Regression lines from Fig. 2 are sequentially arranged in Fig. 4. The slope of each line is a measure of the variance in development time for individuals within that stage. If the variance in development increases with time (i.e. if slow individuals develop progressively slower and fast individuals faster), the slopes of the regression line for each successive stage should decrease. The hypothesis that all slopes were equal was tested by calculating the $95 \%$ confidence interval estimates for each slope. The test was done using both untransformed and arc sine transformed percentages. Interval estimates were found to include
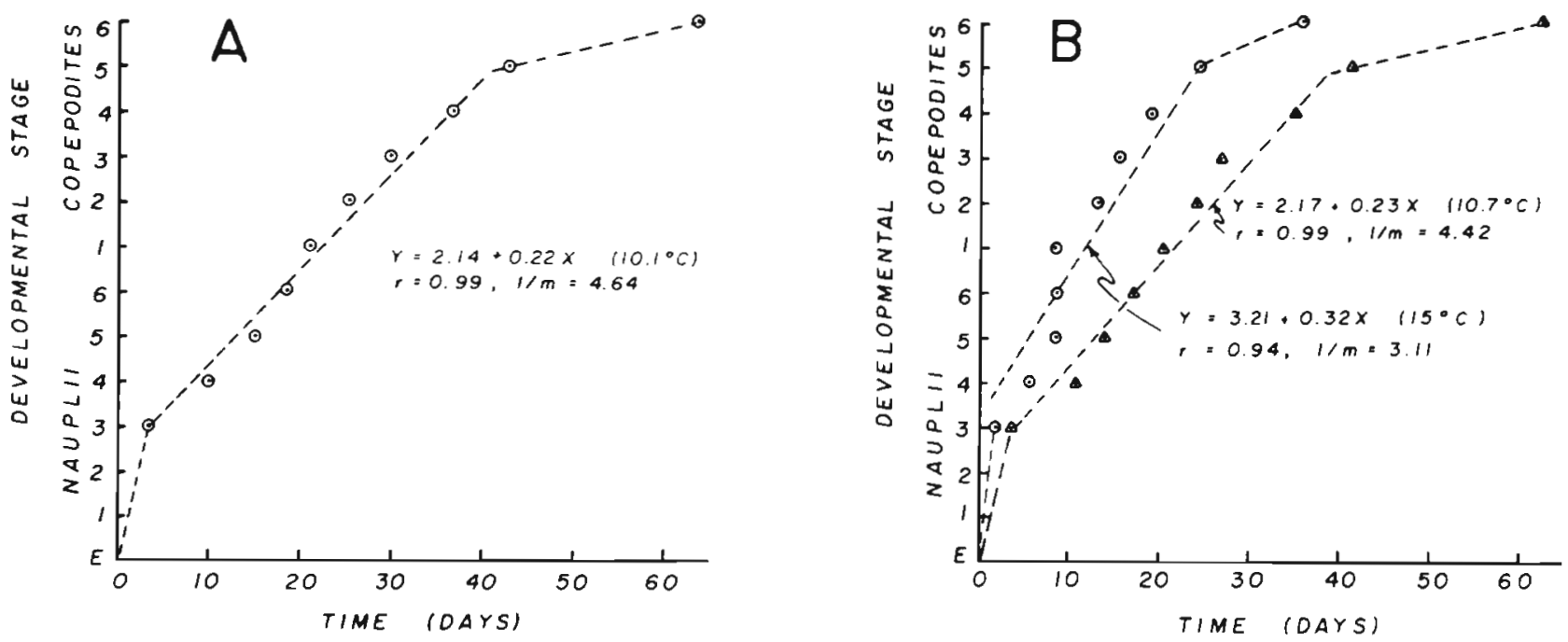

Fig. 3. Calanus marshallae. (A) Progression of developmental stages through time. Dots: times when the median individual had just entered a stage, at $10^{\circ} \mathrm{C}$ (B) Same, at 11 and $15^{\circ} \mathrm{C}$ 


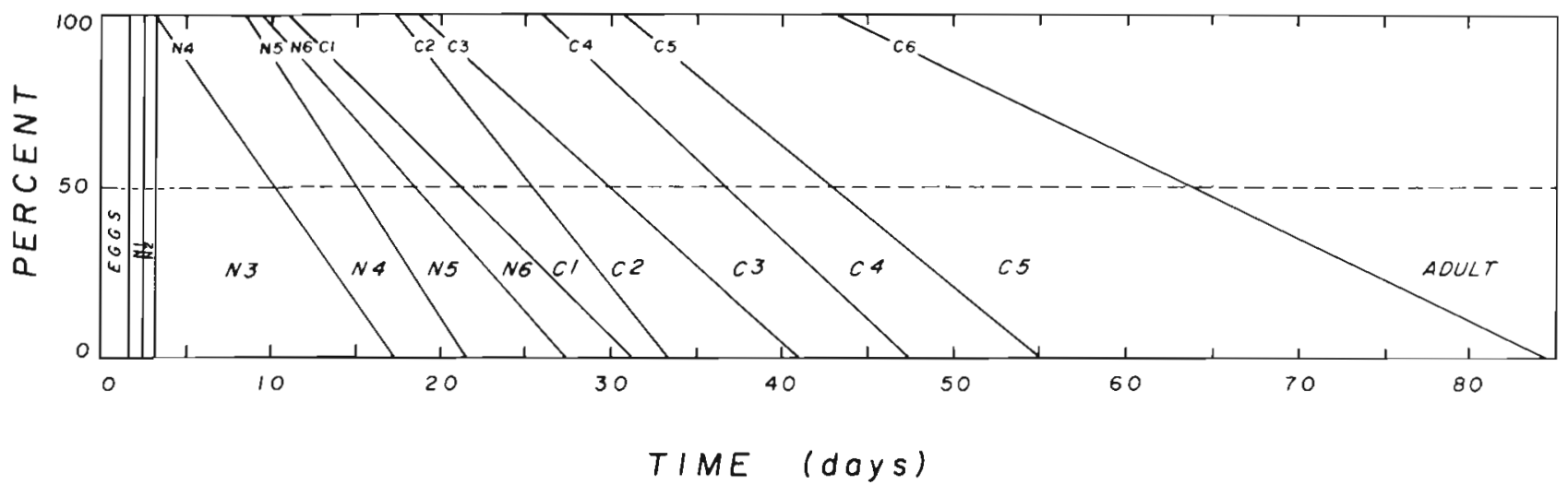

Fig. 4. Calanus marshallae. Development of each indicated stage at $10^{\circ} \mathrm{C}$ showing the least squares regression lines from Fig. 2

all slopes except egg through N3, and C6. I conclude that the variance in development to all stages from $\mathrm{N} 4$ to $\mathrm{C} 5$ is about equal. Most of the variance arises during the development of the third nauplius and the fifth copepodite. This suggests that once some variable point of development is reached during the N3 stage, molting of most individuals proceeds on some pre-set nonvariable schedule. Additional variability reappears as C5 individuals prepare for the molt to adult. I therefore conclude that both the N3 and C5 stages have some 'special' status during the developmental process, a matter discussed later in this paper.

\section{Variability in development among families}

Most of the $10^{\circ} \mathrm{C}$ experiments were initiated from a single clutch of eggs so that variations in stage-specific development times among families could be investigated. The age of the median individual at each developmental stage for each of the 9 family lines was calculated, and is listed in Table 2. Due to shortage of data, only median development times to copepodite Stages 2, 3, 5 and 6 could be analysed for differences among families.

Several conclusions may be drawn from the data listed in Table 2. First, among families the range in days between the arrival of the median individual to a given stage is great. The median individual from a fast-developing clutch (e.g. ' $F$ ') could be 2 developmental stages ahead of the median individual from a slower developing clutch (e.g. 'G'). In 'G', the median $\mathrm{Cl}$ appeared at $26.7 \mathrm{~d}$ while in ' $\mathrm{F}$ ' the median individual was a $\mathrm{C} 3$ at $26.1 \mathrm{~d}$.

Second, if copepods in one experiment got ahead of another experiment for whatever reason, they did not necessarily keep this lead through to the end. For example, individuals in the ' $\mathrm{H}$ ' experiment were the first to arrive at $\mathrm{C} 2$ and $\mathrm{C} 3$, the second to $\mathrm{C} 5$ but last to
Table 2. Calanus marshallae. Time (d) when the median individual had reached each listed developmental stage, for 12 separate experiments at $10^{\circ} \mathrm{C}$. Times in parentheses are inferred from a single data point. With the exception of $\mathrm{C}, \mathrm{H}$ and I, all experiments began with eggs from a single clutch of an individual female. All experiments conducted under continuous low light except I (12:12 LD cycle)

\begin{tabular}{|c|c|c|c|c|c|c|c|}
\hline \multirow{2}{*}{ Code } & \multicolumn{6}{|c|}{ Copepodite stage } & \multirow{2}{*}{$\begin{array}{l}\text { Elapsed } \\
\text { time } \\
\text { C5 to C6 }\end{array}$} \\
\hline & $\mathrm{C} 1$ & $\mathrm{C} 2$ & $\mathrm{C} 3$ & $\mathrm{C} 4$ & $\mathrm{C} 5$ & C6 & \\
\hline $\mathrm{C}$ & & 23.2 & $(<28)$ & 35.7 & 45.0 & 65.3 & 20.3 \\
\hline $\mathrm{D}$ & & $(24,6)$ & 26.0 & & 44.9 & 68.3 & 23.4 \\
\hline$E$ & 26.1 & 28.9 & 31.6 & 38.0 & 45.3 & 68.1 & 22.8 \\
\hline$\vec{F}$ & & 21.9 & 26.1 & & (39) & 59.1 & 20 \\
\hline$G$ & 26.7 & 30.6 & 35.2 & 41.8 & 47.7 & 61.4 & 13.7 \\
\hline $\mathrm{H}$ & & 21.5 & 23.6 & 32.0 & 39.1 & 69.8 & 30.1 \\
\hline I & 18.5 & 22.2 & 24.1 & & 36.6 & 63.0 & 26.4 \\
\hline $\mathrm{J}$ & 19.2 & 22.7 & 29.6 & 32.9 & 40.3 & 51.9 & 11.6 \\
\hline $\mathrm{K}$ & 23.8 & 27.3 & 31.8 & 35.5 & 42.5 & 59.8 & 17.3 \\
\hline $\mathrm{L}$ & & 25.4 & 32.0 & 40.9 & 43.4 & 52.7 & 9.3 \\
\hline$M$ & 24.7 & $(27.8)$ & 31.7 & & 42.2 & 67.7 & 25.5 \\
\hline $\mathrm{N}$ & 20.5 & 24.2 & 28.9 & 33.6 & 40.2 & 63.5 & 23.3 \\
\hline$\frac{N}{\text { (early) }}$ & 19.0 & 23.8 & 28.5 & 33.8 & 39.6 & 59.1 & \\
\hline $\begin{array}{c}\mathrm{N} \\
\text { (late) }\end{array}$ & 20.9 & 24.5 & 29.3 & 33.5 & 41.1 & 69.4 & \\
\hline Average & 22.8 & 24.8 & 29.1 & 36.3 & 42.5 & 62.5 & 20.0 \\
\hline
\end{tabular}

arrive at female. Conversely, individuals in ' $G$ ' were last to arrive at the younger stages but fifth to become female. The rank-order arrival to Stages C2, C3 and C5 among the twelve $10^{\circ} \mathrm{C}$ experiments was tested for concordance using Kendall's coefficient of concordance, ' $W$ ', from Daniel (1978). The result was $W=0.59$ (significant at the 0.005 level); there was substantial agreement among the ranks as to fast and slow developing clutches. The situation was reversed when rank-order arrivals to Stages $\mathrm{C} 3-\mathrm{C} 5-\mathrm{C} 6$, and $\mathrm{C} 5-\mathrm{C} 6$ were examined. In these 2 cases, no concordance was found ( $\mathrm{W}=0.39, \mathrm{p}=0.3 ; \mathrm{W}=0.54, \mathrm{p}=0.4$ respectively) because in 4 of the 12 experiments, individuals 
molted from C5 to female at a much slower rate (C, D, $\mathrm{H}, \mathrm{I})$, in 4 at a faster rate $(\mathrm{G}, \mathrm{J}, \mathrm{K}, \mathrm{L})$ and in 4 at intermediate rates $(E, F, M, N)$ as compared to molting during the earlier copepodite stages. When only the 9 clutches representing different families were analysed by the same methods, the same result was found. All of this again suggests that development through the later stages (copepodite Stage 5 in particular) is controlled by a genetic mechanism different from that for development from N3 to C5.

\section{Variability in development within a family line}

The hypothesis was tested that the eggs which were the first to hatch from a clutch developed at a faster rate than those which hatched last. In this experiment, the first 20 nauplii which hatched from a clutch of 40 eggs were maintained separately from the last 20 nauplii. The median development times of these 2 groups are shown at the bottom of Table 2 as experiments ' $N$ early' and ' $\mathrm{N}$-late'. (The pooled results of this experiment are ' $\mathrm{N}$ ' in Table 2.) The median individual within the early-hatching group became an adult $59.5 \mathrm{~d}$ after hatching whereas among the late-hatching group, adulthood was reached $9 \mathrm{~d}$ later, $68.1 \mathrm{~d}$ after hatching.

\section{Change in length with stage}

The relation between body length and developmental stage for Calanus marshallae (Fig. 5) shows that change in length with stage occurred in 4 linear phases. First, nauplius (N) Stages 1 and $2(0.017 \mathrm{~mm}$ stage ${ }^{-1}$ ); second, N2 through N6, $0.06 \mathrm{~mm}$ stage $^{-1}$; third, N6 through third copepodite (C), $0.29 \mathrm{~mm}$ stage $^{-1}$; fourth, C3 through C6, $0.41 \mathrm{~mm}$ stage $^{-1}$. Mean lengths of nauplii from the laboratory and field were equal. Mean length of each copepodite stage from the Lab-77 experiments was significantly greater than Lab-76 copepodites (paired t-tests). With the exception of $\mathrm{C} 4$ and C5, laboratory-raised individuals were significantly longer than wild individuals. These results suggest that the laboratory conditions under which the copepods were raised were as good as if not better than conditions in the field.

\section{Maternal effects on terminal size}

Table 3 shows that laboratory females (Lab-77) were significantly longer than field females and that the range in length of laboratory females was greater than field females. Since the laboratory conditions represent a nearly constant environment with food in excess,

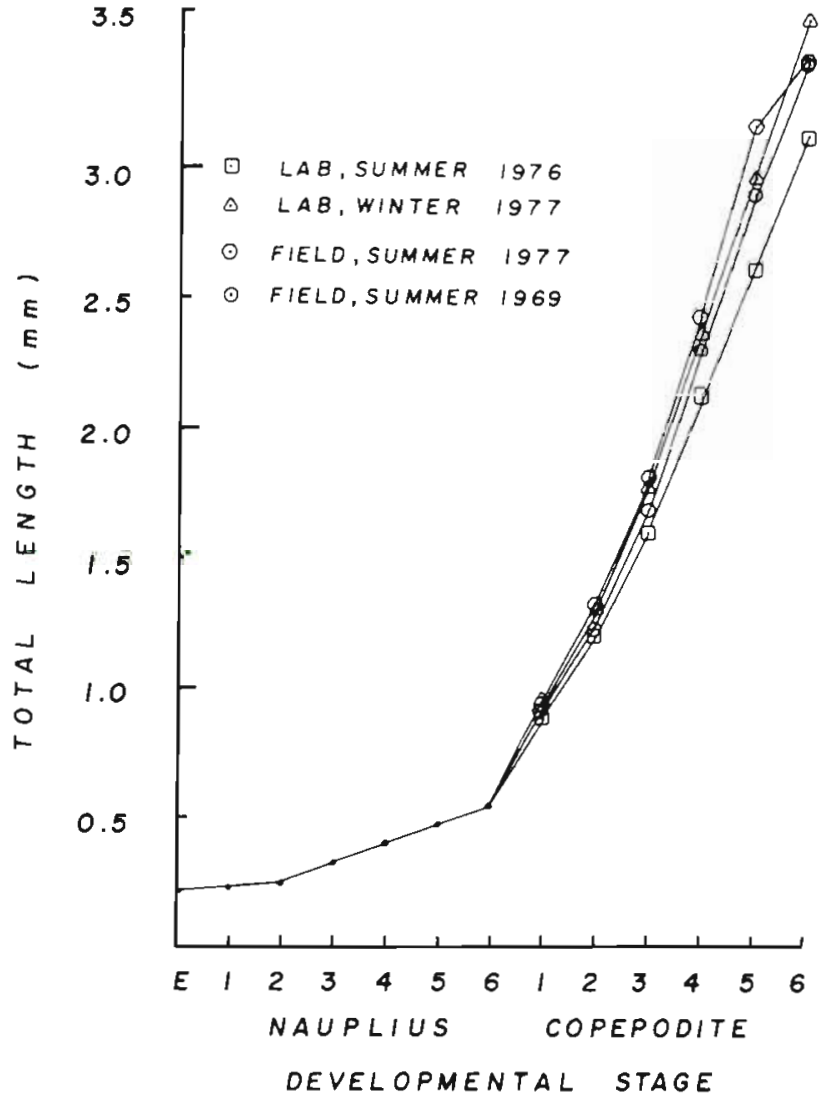

Fig. 5. Calanus marshallae. Comparison of average lengths of laboratory-raised and field-collected developmental stages. Lengths of nauplii were the same in both lab and field specimens so data are shown by a single dot for each stage

the great range in terminal size may be due almost entirely to genetic effects. This hypothesis was further examined by comparing terminal size of daughters with that of their mothers (Fig. 6). The trend of the data suggests that larger mothers produce smaller daugh-

Table 3. Calanus marshallae. Comparison of total length of females either raised in the laboratory or collected off the Oregon coast. Laboratory females were significantly longer than field females $(t=7.04 ; 270 \mathrm{df})$

\begin{tabular}{|ccccc|}
\hline $\begin{array}{c}\text { Size classes } \\
(\mathrm{mm})\end{array}$ & $\begin{array}{c}\text { Lab 1977 } \\
\text { No. of } \\
\text { individuals }\end{array}$ & $\begin{array}{c}\text { Field 1977 } \\
\text { No. of } \\
\text { individuals }\end{array}$ & $\%$ \\
\hline $2.60-2.76$ & 0 & 0.0 & 1 & 0.1 \\
$2.80-2.96$ & 0 & 0.0 & 1 & 0.1 \\
$3.00-3.16$ & 2 & 2.0 & 79 & 6.1 \\
$3.20-3.36$ & 14 & 14.1 & 400 & 30.8 \\
$3.40-3.56$ & 22 & 22.2 & 572 & 44.1 \\
$3.60-3.76$ & 44 & 44.4 & 213 & 16.4 \\
$3.80-3.96$ & 16 & 16.2 & 29 & 2.2 \\
$4.00-4.16$ & 1 & 1.0 & 2 & 0.2 \\
Total & 99 & & 1.297 & \\
\hline
\end{tabular}




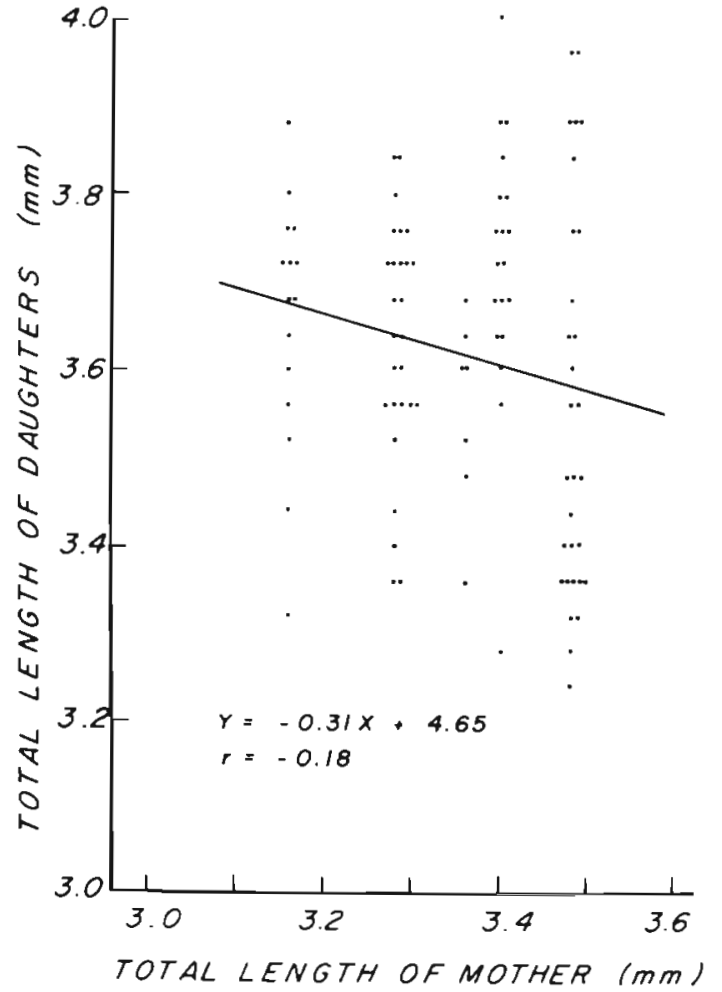

Fig. 6. Calanus marshallae. Scatter diagram showing length of daughters vs length of mother. Slope of regression line was not significantly different from zero

ters on the average, although the slope of the regression line was not significantly different from zero $(\mathrm{F}=3.24,1,98 \mathrm{df})$. Only $3 \%$ of the variability in terminal size of all daughters was explained by size of their mothers. I conclude that length of a female has little direct influence on the average length of her daughters, and that terminal size of offspring within any given clutch of eggs is extremely variable. The observed differences in total length between laboratory and field females may have resulted from any number of vagaries of differences in diet between lab and field, as well as variable water temperature in the field. Size-selective predation is an alternate hypothesis, but this factor was not examined during my study.

\section{Length-weight relations}

Length-weight data were only available for Stages $\mathrm{C} 4$ through $\mathrm{C} 6$. The coefficients of the power function $\left(\mathrm{W}=\mathrm{a} \mathrm{L}^{\mathrm{b}}\right.$ ) were determined by least-squares methods after transforming both $\mathrm{L}$ and $\mathrm{W}$ to logarithms. The relation was $\mathrm{W}=2.00 \mathrm{~L}^{3.94}(\mathrm{n}=57 ; \mathrm{r}=0.96 ; 95 \%$ confidence interval of the slope \pm 0.02 ). It seems that a cubic relation ( $\mathrm{W}=\mathrm{aL}^{3}$ ) does not apply to older copepodite stages of Calanus marshallae. Individuals in the older stages are heavier than the cubic law would predict probably because they contain appreciable amounts of wax esters.

\section{Change in weight with stage and time}

Weight gained between egg and N4 was small, but from N4 to C6, weight was gained at on overall stagespecific rate of $0.73 \mu \mathrm{g} \mathrm{stage}$ (Fig. $^{-1}$ A). The functional relation between change in weight and time was examined by plotting dry weight of stages vs the cumulative median development time (Fig. $7 \mathrm{~B}$ ) using the development time data from the $10^{\circ} \mathrm{C}$ experiments. Three phases in the growth processes were seen: (1) egg through N4: weight was gained at a rate of $0.050 \mu \mathrm{g}^{-1} \mathrm{~d}^{-1}$; (2) N5 through C5: $0.176 \mu \mathrm{g} \mu \mathrm{g}^{-1}$ $\mathrm{d}^{-1}$; (3) C5 to female: $0.024 \mu \mathrm{gg}^{-1} \mathrm{~d}^{-1}$. Even though growth rate on a per stage basis was constant from N4 through female, growth on a daily basis was slow between $\mathrm{C} 5$ and female for example, because of the extended interval between recruitment of $\mathrm{C} 5$ to adult female. Females do gain the weight predicted by the weight-stage linear regression (from Fig. 7), but it takes them longer to achieve the predicted weight.

\section{DISCUSSION}

\section{Survivorship}

Survivorship from egg to adult in the $10^{\circ} \mathrm{C}$ experiments averaged $41 \%$. Similar results were obtained by Mullin \& Brooks $(1967,1970)$ for Rhincalanus nasutus and Calanus pacificus. Hirche (1980) reported $12 \%$ for Calanoides carinatus, and Paffenhöfer (1970) 41 to $100 \%$ for C. pacificus. In Paffenhöfer's experiments, mortality rates were very nearly zero after the first copepodite stage but in my study, mortality did not reach zero until the fourth copepodite stage. Virtually all Calanus marshallae copepodites which died did so during the molt, an observation also noted by Raymont \& Gross (1942) and Corkett (pers. comm.) for Calanus finmarchicus.

\section{Sex ratio}

Of 137 adults produced in the laboratory, only 1 was a male. Males did not appear in Mullin \& Brook's (1970) experiments on Calanus pacificus, but the sex ratio was $1: 1$ for Rhincalanus nasutus cultured at the same time under the same conditions. Hirche (1980) obtained only females of Calanoides carinatus and Calanus helgolandicus. Conover (1965) and Tomasini \& Petit (1977, cited in Hirche 1980) maintained fifth 

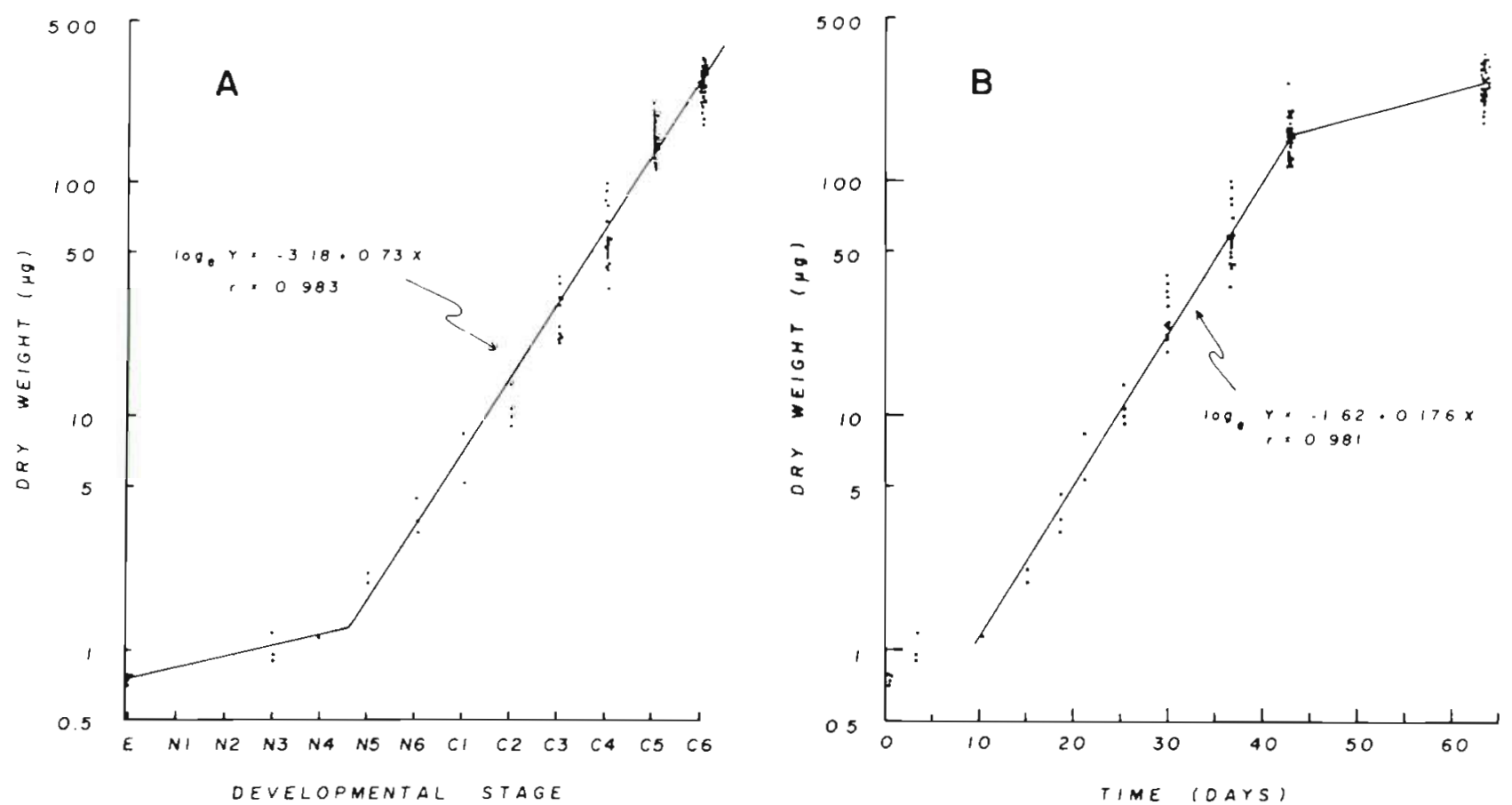

Fig. 7 Calanus marshallae. (A) Change in weight with developmental stage. (B) Change in weight with time. Three linear growth phases are seen: (1) from Day 0 to Day 10 (Egg to N4); (2) from Day 10 to Day 43 (N4 to C5); (3) from C5 to female. Specific growth rate from $\mathrm{N} 4$ to $\mathrm{C} 5$ was $0.176 \mu \mathrm{g} \mu \mathrm{g}^{-1} \mathrm{~d}^{-1}$

stage Calanus hyperboreus and C. carinatus respectively in the laboratory and obtained only females although some males appeared in Conover's experiments on copepods collected during winter. Both Paffenhöfer (1970) and Vidal (pers. comm.) got as many as 25 to $40 \%$ males respectively in their laboratory cultures of $C$. pacificus. Landry (1983) reported a proportion of male $R$. nasutus and $C$. pacificus of 0.44 and 0.31 . Paffenhöfer suggested that both food concentration and phytoplankton species composition may be important for sex determination, but in Vidal's (pers. comm.) experiments, food concentration had no apparent effect on sex ratio.

An excess of females is frequently observed in nature, and differential mortality of adults has been suggested (Marshall \& Orr 1955) as an explanation. Calanus marshallae averaged $12.0 \%$ males in 195 vertical plankton net hauls taken off Newport, Oregon, from 1969 to 1972 (Peterson \& Miller 1976) and $13.6 \%$ in 360 samples collected from discrete depths during the summer of 1977 (Peterson 1980). Similar results (10\% male) were reported by Marshall \& Orr (1955) for Calanus finmarchicus in the Clyde Sea. Raymont \& Gross (1942) found that male $C$. finmarchicus survived only 1 to $2 \mathrm{wk}$ whereas females lived more than $9 \mathrm{wk}$ in the laboratory. They also showed that males took very little if any food suggesting that the mouthparts were reduced. Hirche (1980) reported that Calanoides carinatus males lived only 10 to $12 \mathrm{~d}$ in the laboratory. Very different results were found for C. marshallae: both males and females survived for at least $8 \mathrm{wk}$ in the laboratory. Males have fully developed mouthparts and produce copious amounts of fecal pellets in the laboratory, suggesting that they do feed and that skewed sex ratios in nature are not due to higher physiological mortality of males.

\section{Development time}

Individual Calanus marshallae developed from egg to adult at a much slower rate than other related species. Corkett (pers. comm.) found for Calanus finmarchicus an egg-to-adult development time of $35 \mathrm{~d}$ at $10^{\circ} \mathrm{C}$. Calanus pacificus reached adulthood after about 23 and $45 \mathrm{~d}$ at 15 and $10^{\circ} \mathrm{C}$ respectively (Mullin \& Brooks 1970, Paffenhöfer 1970), and $20 \mathrm{~d}$ at $15^{\circ} \mathrm{C}$ (Landry 1983). Thompson (1982) reported development times for Calanus spp. (collected from the southern North Sea) of 26 and $42 \mathrm{~d}$ at 15 and $10^{\circ} \mathrm{C}$, and Hirche (1980), $22 \mathrm{~d}$ at $15^{\circ} \mathrm{C}$ for Calanoides carinatus. C. marshallae reached adulthood after 36 and $64 \mathrm{~d}$ at the same 2 temperatures. Each of these estimates are $34 \%$ greater than those for other Calanus species. 


\section{Growth}

In my experiments, log-phase phytoplankton was usually added to the copepod growth chambers in dense enough concentrations to at least color the water lightly. Some evidence that the copepods were not food-limited comes from the facts that body lengths of all nauplii and of copepodites Stages 1 to 3 and adult females in the laboratory were the same as (or in adult females, greater than) field-collected individuals. This contrasts with the results of Paffenhöfer (1970) whose laboratory female Calanus pacificus, raised on various diatom species, were significantly smaller than wild females, and only achieved the lengths of wild females with Gymnodinium splendens as food. Curiously, laboratory-raised C4 and C5 Calanus marshallae in my experiments were shorter than wild specimens. A likely explanation is that in the field C4 and C5 are diel migrators, which grow at temperatures that average lower than $10^{\circ} \mathrm{C}$, and experience a different food environment compared to non-migrating stages. Other evidence that feeding conditions were adequate comes from experiments on the fecundity of C. marshallae. Maximum egg production rates of 25 eggs female f $^{-1}$ $\mathrm{d}^{-1}$ occurred at 3,500 cells $\mathrm{ml}^{-1}$ of Thalassiosira weissflogii (Peterson 1980), a concentration near the low end of the range in food concentration used in the development time experiments.

Growth in weight of Calanus marshallae was exponential from N4 to $\mathrm{C} 5$. This result differs from laboratory studies on most other coastal copepods in which specific growth rates decreased through the late copepodite stages, as shown for Rhincalanus nasutus, Calanus helgolandicus and Calanus pacificus (Mullin \& Brooks 1970, Paffenhöfer 1976, Vidal 1980), and for Pseudocalanus elongatus and Temora longicornis (Paffenhöfer \& Harris 1976, Harris \& Paffenhöfer 1976). My result may have been obtained because growth rates were calculated from weights of laboratoryraised N3 to C3 but wild C4 to C6. Hakanson (1984) has shown that wild $\mathrm{C} 5$ of $C$. pacificus are considerably heavier than laboratory-raised individuals, but that weights of laboratory and wild C4 were equal. Similarly, Paffenhöfer's (1976) diatom-raised C5 and female $C$. pacificus reared on diatoms were lighter than those raised on dinoflagellates or from the wild. If my $\mathrm{C} 5$ and adult C. marshallae raised on Thalassiosira weissflogii grew similarly to Hakanson's C. pacificus raised on $T$. weissflogii, and to Paffenhöfer's $C$. pacificus raised on diatoms, then specific growth rates of C. marshallae (if calculated from weights of laboratory-raised individuals) would have declined between C4 and adult female. Hakanson (1984) suggested that differences in lipid (wax ester) content in laboratory vs 'wild' phytoplankton may explain observed differ- ences in weight between laboratory and wild C5 and adult Calanus. The decline in growth rate with stage in laboratory-raised copepods may be due to lipid-limitation of growth.

\section{Development}

The overall pattern of development of Calanus marshallae largely conforms to patterns described by Landry (1983) for the coastal copepods Acartia clausi, Acartia tonsa, Rhincalanus nasutus, Calanus pacificus, Labidocera trispinosa, Paracalanus parvus and Pseudocalanus spp. First, the duration of the pre-feeding naupliar stages is relatively short, only $42 \mathrm{~h}$ for $\mathrm{N} 1+\mathrm{N} 2$ in C. marshallae. Second, the first-feeding stage, N3, has the second-longest duration of any stage. Third, the female $\mathrm{C} 5$ had the longest duration. Landry (1983) suggested that the first 2 naupliar stages are short because they do not feed, that N3 is long because it needs time to recover weight lost during the previous 2 non-feeding stages, and that the extended duration of $\mathrm{C} 5$ is needed to accumulate lipid reserves. Landry's observation that egg development times cannot be used to predict egg-to-adult development times holds for C. marshallae as well. The primary difference between the development of C. marshallae and other coastal copepods is the sigmoidal pattern of stage-bystage developmental times. In particular, development from N3 through N6 was progressively faster, with N6 the stage with the shortest duration. This was followed by progressively slower development through each copepodite stage.

\section{Adaptive features of Calanus development}

The arguments presented here assume that any deviations from isochronal development will have evolved in response to differential mortality rates among developmental stages. Stages with a long duration are considered to be relatively 'safe' while those with a short duration are 'vulnerable'. Along these lines, Miller et al. (1977) and Johnson (1981) argued that the observed rapid development through late copepodite stages of Acartia species evolved in response to high mortality rates of older copepodite stages, especially of the adults.

The pattern in Calanus marshallae was rapid development to N3, followed by quasi-isochronal development to $\mathrm{C} 5$ then extremely slow development to adult. One can hypothesize that the pattern evolved in response to constantly high egg and N1 + N2 mortalities, or both, moderate death rates through the other nauplii and early copepodites, followed by greatly 
enhanced survival rates of $\mathrm{C} 5$ and adults. Evidence in support of this model follows.

First, compared to other neritic copepods, the eggs of Calanus marshallae hatch quickly: $1.8 \mathrm{~d}$ at $10^{\circ} \mathrm{C}$ compared to $3.3 \mathrm{~d}$ for Acartia clausii (Landry 1976), $3.5 \mathrm{~d}$ for Pseudocalanus minutus and $4.1 \mathrm{~d}$ for Tortanus discaudatus (McLaren 1966). Second, in the field, mortality of eggs seems to be high. From 360 samples collected from discrete depths along 9 zonal transects off the Oregon coast in July-August 1977 (Peterson 1980), the ratio, number of N3 recruits produced each day: number of eggs produced per day, averaged 0.017 (Table 4). Furthermore, on 3 dates when N1, N2, and

Table 4. Calanus marshallae. Estimated number of daily recruits from egg, $\mathrm{N} 1+\mathrm{N} 2$ and $\mathrm{N} 3$ stages, calculated from abundance estimates of these stages in samples collected off the Oregon and Washington State coast during summer 1977. On average, about $1.7 \%$ of the eggs produced each day reach the third nauplius stage

\begin{tabular}{|c|c|c|c|c|c|}
\hline \multirow{2}{*}{$\begin{array}{c}\text { Date } \\
(1977)\end{array}$} & \multicolumn{3}{|c|}{ Daily recruits } & \multirow{2}{*}{$\begin{array}{c}\text { Ratio } \\
\mathrm{N} 1+\mathrm{N} 2 / \\
\text { Eggs }\end{array}$} & \multirow{2}{*}{$\begin{array}{l}\text { Ratio } \\
\text { N3/ } \\
\text { Eggs }\end{array}$} \\
\hline & $\begin{array}{c}\text { Eggs } \\
\mathrm{d}^{-1}\end{array}$ & $\begin{array}{c}\mathrm{N} 1+\mathrm{N} 2 \\
\mathrm{~d}^{-1}\end{array}$ & $\begin{array}{c}\mathrm{N} 3 \\
\mathrm{~d}^{-1}\end{array}$ & & \\
\hline 8 Jul & 537,806 & 2,245 & 1,668 & .004 & .003 \\
\hline $15 \mathrm{Jul}$ & $1,008,131$ & - & 18,533 & - & .018 \\
\hline $21 \mathrm{Jul}$ & 67,379 & 540 & 802 & .008 & .012 \\
\hline $23 \mathrm{Jul}$ & 202,316 & - & 23,879 & - & .031 \\
\hline $24 \mathrm{Jul}$ & 401.620 & 1,114 & 2,679 & .003 & .007 \\
\hline $26 \mathrm{Jul}$ & 187,948 & - & 932 & - & .005 \\
\hline $29 \mathrm{Jul}$ & 880,510 & - & 4,535 & - & .005 \\
\hline 4 Aug & 97,874 & - & 1.640 & - & .017 \\
\hline 13 Aug & 2,074 & - & 109 & - & .053 \\
\hline Average & & & & & .017 \\
\hline
\end{tabular}

N3 were each enumerated (Table 4), the number of recruits from these stages were about equal, suggesting that almost all mortality came during the egg stage. If this has been true over evolutionary time, selection would have shortened the time spent in the vulnerable egg. The evolution of an egg which hatches quickly may also be related to egg sinking rates. The eggs of C. marshallae sink at a rate of $36.0 \mathrm{~m} \mathrm{~d}^{-1}$ ( $\mathrm{n}=68$; Peterson 1980). In $1.8 \mathrm{~d}$ an egg could sink well below the food-rich upper 0 to $10 \mathrm{~m}$ mixed layer off Oregon. The rapid development to a swimming nauplius would aid in the return to the euphotic zone. In contrast, the eggs of $A$. clausii sink at rates of only $5 \mathrm{~m}$ $\mathrm{d}^{-1}$ (Valentin 1972) so would not leave the euphotic zone during their 3 to $4 \mathrm{~d}$ developmental period. Egg sinking does not seem to be a problem for the Oregon population of $C$. marshallae because eggs were found to be most abundant between 0 and $10 \mathrm{~m}$ (Peterson et al. 1979, Peterson 1980), but may be important where upwelling is limited (such as in the Bering Sea). Eggs of Calanus spp. are known from English Channel sediments (Williams \& Lindlay 1980).

Another key stage in the life history of Calanus marshallae is the third nauplius, which I considered as having some special developmental status because: (1) this stage has a relatively long duration and (2) it shows the most variable development time. I suggest that this is the case because a number of developmental events take place during N3, including a general thickening of the ectoderm, a greater development of muscles which work the limbs, development of the gut, and initiation of development of the genital system as noted by Marshall \& Orr (1955, p. 46-47). In my experiments, the N3 gained very little weight compared to the later naupliar stages, suggesting that most of the energy it uses goes into production of new machinery rather than new biomass. In order to assure that this stage has sufficient energy to complete development (even when food is scarce), individuals may be able to subsist on yolk alone. To test this hypothesis, a number of batches of eggs were hatched in $0.45 \mu \mathrm{m}$ filtered seawater. Development proceeded to N3 at the regular pace, but no further. Individual N3 survived for $10 \mathrm{~d}$ on average.

Other species of Calanus may have a similar early life history. Eggs of C. finmarchicus hatch quickly $\left(40 \mathrm{~h}\right.$ at $\left.10^{\circ} \mathrm{C}\right), \mathrm{N} 3$ is reached within $3 \mathrm{~d}$ (Marshall \& Orr 1955), and the N3 stage is long-lived (Lebour 1916). Fernandez (1979) found that eggs of $C$. pacificus hatch within $24 \mathrm{~h}$ at $15^{\circ} \mathrm{C}$, that $\mathrm{N} 3$ was reached in $1.5 \mathrm{~d}$, and that at $15^{\circ} \mathrm{C}$, starved $\mathrm{N} 3$ lived up to $6 \mathrm{~d}$. However, in his experiments, the nauplii all molted to N4 before dying. From Landry (1983) and Thompson (1982), it could be concluded that many coastal copepods share this pattern of rapid development to the first feeding stage.

After N3 is successfully passed, all other stages have a pre-set schedule with little change in variability of stage duration. Stage durations become progressively shorter from N3 to N6. The sixth nauplius lasted only $2.6 \mathrm{~d}(4.1 \%$ of the total development time) which was surprising because many morphological changes take place here. Individuals develop maxillules, maxillae, maxillipeds, and 2 pairs of swimming legs along with the musculature to operate them. Landry (1978) has shown that for some copepod predators, late nauplii stages are preferred as prey over younger stages, therefore if predation pressure is intense enough, selection could act to accelerate development of the N6. Rapid development through N6 is not common however, only being found by Thompson (1982) for Pseudocalanus elongatus and Calanus sp., and for Labidocera trispinosa in Landry's (1983) study of 7 coastal species.

At C5, developmental problems may be responsible 
for lengthening the stage duration: the copepods develop gonads and make a decision about diapause. If they molt to adult, the oil sac is partially resorbed and the gonads develop. The differential ability of individuals to handle all of these events likely explains why some arrive to adulthood faster than others. All coastal copepods studied to date have delayed C5 development (Landry 1983), but Calanus marshallae seems to have the longest duration at this stage.

Some insights into the heritability of several fitness characteristics were gained from this study. First, total development time from N3 to older copepodite stages was highly variable among families suggesting that this is not a major factor affecting individual fitness. This is further supported by the observation that families that arrived to $\mathrm{C} 5$ first did not reach adulthood first. Additional among-family variability in development time came during the fifth copepodite. Such a change in rate of development and overall variability in development among families was noted by McLaren \& Corkett (1978) who found that for Pseudocalanus the variability in the $\mathrm{N} 1$ to $\mathrm{C} 1$ developmental time was greater than for the period N1 to adult. This suggests that the overall egg-to-adult developmental process comes under control of different genetic mechanisms at several points. For Calanus marshallae, changes in genetic control probably come at N3 and C5 stages.

Another parameter often associated with fitness is female body size. For Calanus marshallae, length of females was highly variable. Also, there was no relation between total length of females and total length of their female offspring. These facts suggest that there is no selective advantage to being large, a conclusion supported by the observation that fecundity among individual female C. marshallae is unrelated to body length (Peterson 1980). MacLaren \& Corkett (1978) found the opposite, that large female Pseudocalanus produce large daughters. This result would be expected because fecundity in this copepod is positively correlated with body size.

Acknowledgements. This research was supported by National Science Foundation grants OCE 76-21958 and OCE 78-12296. Comments on an earlier draft of this manuscript by B. W. Frost, M. M. Mullin and G.-A. Paffenhöfer are appreciated. Comments by B. Beckman, H. Dam, G. McManus and 3 anonymous reviewers greatly improved the final version.

\section{LITERATURE CITED}

Conover, R. J. (1965). Notes on the moulting cycle, development of sexual characters and sex ratio in Calanus hyperboreus. Crustaceana 8: 308-320

Daniel, W. W (1978). Applied nonparametric statistics. Houghton Mifflin Co., Boston

Fernandez, F. (1979). Nutrition studies in the nauplius larva of
Calanus pacificus (Copepoda:Calanoida). Mar. Biol. 53: 131-147

Frost, B. W. (1974). Calanus marshallae: a new species of calanoid copepod closely allied to the sibling species $C$. finmarchicus and C. glacialis. Mar. Biol. 26: 77-99

Guillard, R. R. L.; Ryther, J.H. (1962). Studies on marine planktonic diatoms. Can. J. Microbiol. 8: 229-239

Hakanson, J. L. (1984). The long and short term feeding condition in field-caught Calanus pacificus, as determined from the lipid content. Limnol. Oceanogr 29: 794-804

Harris, R. P., Paffenhöfer, G.-A. (1976). Feeding, growth and reproduction of the marine planktonic copepod Temora longicornis Müller. J. mar. biol. Ass. U. K. 56: 675-690

Hirche, H.-J. (1980). The cultivation of Calanoides carinatus Kroyer (Copepoda:Calanoida) under different temperature and food conditions - with a description of eggs and nauplii. J. mar. biol. Ass. U. K. 60: 115-125

Johnson, J. K. (1981). Population dynamics and cohort persistence of Acartia californiensis (Copepoda:Calanoida) in Yaquina Bay, Oregon. Ph. D. thesis, Oregon State University

Landry, M. R. (1976). Population dynamics of the planktonic marine copepod Acartia clausi Giesbrecht, in a small temperate lagoon. Ph. D. thesis, University of Washington

Landry, M. R. (1978). Predatory feeding behavior of a marine copepod, Labidocera trispinosa. Limnol. Oceanogr 23: 1103-1113

Landry, M. R. (1983). The development of marine calanoid copepods with comment on the isochronal rule. Limnol. Oceanogr. 28: 614-624

Lebour, M.V (1916). Stages in the life history of Calanus finmarchicus (Gunnerus), experimentally reared by Mr. L. R. Crawshay in the Plymouth laboratory. J. mar. biol. Ass. U. K. 11: 1-17

Marshall, S. M., Orr, A. P. (1955). The biology of a marine copepod Calanus finmarchicus (Gunnerus). Oliver and Boyd, Edinburgh

McLaren, I. A. (1966). Predicting development rate of copepod eggs. Biol. Bull mar. biol. Lab., Woods Hole 131: $457-469$

McLaren, I. A., Corkett, C. J. (1978). Unusual genetic variation in body size, development times, oil storage, and survivorship in the marine copepod Pseudocalanus. Biol. Bull. mar. biol. Lab., Woods Hole 155: 347-359

Miller, C. B., Johnson, J. K., Heinle, D. R. (1977). Growth rules in the marine copepod genus Acartia. Limnol. Oceanogr 22: 326-335

Mullin, M. M., Brooks, E. R. (1967). Laboratory culture growth rate, and feeding behavior of a planktonic marine copepod. Limnol. Oceanogr. 12: 657-666

Mullin, M. M., Brooks, E. R. (1970). Growth and metabolism of two planktonic, marine copepods as influenced by temperature and type of food. In: Steele, J. J. (ed.) Marine food chains. University of California Press, Berkeley, p. 74-95

Paffenhöfer, G.-A. (1970). Cultivation of Calanus helgolandicus under controlled conditions. Helgoländer Meeresunters. 20: 346-359

Paffenhöfer, G.-A. (1976). Feeding, growth, and food conversion of the marine planktonic copepod Calanus helgolandicus. Limnol. Oceanogr. 21: 39-50

Paffenhöfer, G.-A., Harris, R. P. (1976). Feeding, growth and reproduction of the marine planktonic copepod Pseudocalanus elongatus Boeck. J. mar. biol. Ass. U. K. 56: $327-344$

Peterson, W. T. (1980). Life history and ecology of Calanus 
marshallae Frost in the Oregon upwelling zone. Ph. D. thesis, Oregon State University

Peterson, W. T., Miller, C. B. (1975). Year-to-year variations in the planktology of the Oregon upwelling zone. Fish. Bull. U. S. 73: 642-653

Peterson, W. T., Miller, C. B. (1976). Zooplankton along the continental shelf off Newport, Oregon, 1969-1972: distribution, abundance, seasonal cycle, and year-to-year variations. Oregon State University, Sea Grant College Publication ORESU-T-76-002 Corvallis

Peterson, W. T., Miller, C. B. (1977). Seasonal cycle of zooplankton abundance and species composition along the central Oregon coast. Fish. Bull. U. S. 75: 717-724

Peterson, W. T., Miller, C. B., Hutchinson, A. (1979). Zonation and maintenance of copepod populations in the Oregon upwelling zone. Deep Sea Res. 26A: 467-494

Raymont, J. E. G., Gross, F. (1942). On the feeding and breeding of Calanus finmarchicus under laboratory conditions. Proc. R. Soc. Edinb., B 61: 267-287
Sokal, R. R., Rohlf, F. J. (1981). Biometry. Second ed. W. H. Freeman and Co. San Francisco

Strathmann, R. R. (1967). Estimating the organic carbon content of phytoplankton from cell volume or plasma volume. Limnol. Oceanogr. 12: 411-418

Thompson, B. M. (1982). Growth and development of Pseudocalanus elongatus and Calanus sp. in the laboratory. J. mar biol. Ass. U. K. 62: 359-372

Valentin, J. (1972). La ponte et les oeufs chez les copepodes du Golfe de Marseille: cycle annual et etude experimentales. Téthys 4: 349-390

Vidal, J. (1980). Physioecology of zooplankton. I. Effects of phytoplankton concentration, temperature, and body size on the growth rate of Calanus pacificus and Pseudocalanus sp. Mar. Biol. 56: 111-134

Williams, R. Lindley, J. R. (1980). Plankton of the Fladen Ground during FLEX 76 III. Vertical distribution, population dynamics and production of Calanus finmarchicus (Crustacea:Copepoda). Mar. Biol. 60: 47-56

This paper was presented by Dr. R. J. Conover; it was accepted for printing on November 12, 1985 